\title{
The Role of Family Functioning in Emotional Regulation Among Undergraduate Students
}

\author{
Ester Ellyana Margaretta ${ }^{1}$ Widya Risnawaty ${ }^{1^{*}}$ \\ ${ }^{1}$ Faculty of Psychology, Universitas Tarumanagara, West Jakarta 11440, Indonesia \\ "Corresponding author. Email: widyar@fpsi.untar.ac.id
}

\begin{abstract}
In general, students are in the age of 18-24 years, which is the transition period from late adolescence to early adulthood so that it is not uncommon during the transition period to arise a variety of problems. The number of stressors in the lecture life makes students must be able to regulate their emotions in order to harmonize the emotional responses that individuals have to the problems or environment they face. As is commonly known that the environment contributes to an important role in shaping the character of each individual. In shaping individual character, emotional and ability, a well-functioning family is needed so that the individual can grow and develop as he should. Therefore, this study aims to find out how big the role of family functioning to emotional regulation in undergraduate students. This study had 114 participants using purposive sampling techniques and measuring instruments in the form of questionnaires in measuring family function and emotional regulation. This study used a simple linear regression analysis that found that there was a positive and significant role of family functioning to emotional regulation in undergraduate students of $27.4 \%$ with $\mathrm{Z}$ $=0.072$ and $\mathrm{t}=6,509>1,981$.
\end{abstract}

Keywords: Emotional regulation, family functioning, undergraduate students

\section{INTRODUCTION}

According to Siswoyo [1], college students are individuals who are studying in higher education, both public and private or institutions that have the same level as universities. In general, undergraduate students have an age range ranging from 18-24 years. Hurlock argues that this period is a developmental transition period from late adolescence to early adulthood [2], during this transitional period sometimes it creates various kinds of problems due to changes experienced and followed by many demands, as well as the pressure given to individuals [3].

Based on a survey conducted by the Buckinghamshire Health Authority in 2002 [4], stressors for students are divided into four types, namely academic stressors, organizational stressors, placement stressors and personal factors. Which produces four kinds of responses, namely: (a) cognitive, such as having difficulty concentrating, understanding and remembering lessons, and inability to solve problems; (b) behaviors, such as procrastination, indolence, drugs and alcohol abuse, and low attendance; (c) physiological, such as insomnia, fatigue and lethargy, and various health problems; and (d) emotional, such as anxiety, motivation and emotional instability that can cause various problems (Heiman \& Kariv, as cited in [5]; \& [6]).

One of the ways needed to minimize stress and the resulting response is to identify the source of the stressors that exist because if you only solve existing problems, one day the same problem will reappear [7]. Therefore, it is necessary to have the ability to identify the source of the problem effectively and efficiently which is able to issue a response with the minimum amount of energy and time [8]. In recognizing the source of the problem efficiently, individuals need to regulate their emotions [9].

According to Balter, emotional regulation is defined as an effort how individuals understand, understand and express their emotions so that they can influence individual behavior to achieve existing goals [10]. According to Frijda [5], through emotional regulation, individual behavior can be increased, reduced or inhibited. Therefore, individuals who are able to regulate negative emotions able to control emotions in many situations [5]. Research conducted by Guiliano [11] shows that individuals who are aware of the appearance of their emotions tend to have a faster ability to improve mood. According to Gross and Barrett [12], how individuals interpret the environment will shape emotional experiences, as well as strategies that will be used in regulating emotions.

The first and foremost environment for each individual is the family [13]. The family plays an important role in the learning process because the family is a place for individuals to lay the basic foundations for their character and emotional development, so it can be said that the family is the main place for individuals to learn about 
emotions, both feeling, responding, causing, expressing and regulating emotions [14].

With a family that instills basic values that must be used as the main foundation, individuals will learn to express emotions by regulating their emotions consciously or unconsciously ([15], \& Izzard \& Harris, as cited in [14]). This is supported in the research of Morris, Silk, Steinberg, Myers and Robinson [16] which shows that the family has an important role in the establishing children's emotional regulation abilities, which includes habituation of behavior in the family, the application of parents as examples and granting children's experiences. Another study by Han, Qian, Gao and Dong [16] explains that there is an influence between emotional stability on the ability to regulate children's emotions.

Morgan et al. [11] assume that families who have closeness between family members are more likely to express emotions or feelings to one another. According to Lubow, Beevers, Bishop and Miller [17], family functioning refers to how all members are able to communicate with one another, do work together and help each other when there is a family member who is physically healthy and emotionally disturbed.

Yahya and Bahri's research [18] shows that the highest problems of college students after financial problems $(77.69 \%)$ are household and family problems (66.15\%), problems with college assignments $(66.15 \%)$, and future problems and education $(66.15 \%)$.

Based on the phenomena obtained about family functioning and emotional regulation in undergraduate students, the researcher wanted to find out about the role of family functioning on emotional regulation in undergraduate students. The result of this research is expected to be useful for the further development of psychological science.

\subsection{Related Work}

Research by Uci and Savira [14] which examined the relationship between the family functioning and emotional regulation in junior high school students found that there was a positive and significant relationship between the two variables. This is reinforced by the research of Saifullah and Djuwairiyah [19] which uses a qualitative research approach with the same variables carried out on adolescents showing that family function plays an important role in fostering a good emotional situation.

\subsection{Our Contribution}

This research was made based on the research of Uci and Savira [14], and Saifullah and Djuwairiyah [19] who have proven that the family function has a positive and significant correlation with emotional regulation, so researchers want to further examine how big is the role of family functioning in emotional regulation. The biggest difference with previous studies lies in the research subjects, namely undergraduate students. The hypothesis in this study is that there is a role of family functioning on emotional regulation in undergraduate students.

\subsection{Paper Structure}

The rest of the paper is organized as follows. Section 1 introduces the preliminaries used in this paper, which include previous research about family functioning and emotional regulation. Section 2 introduce the grand theory about family functioning and emotional regulation. Section 3 presents the research method that contains an overview of participants and measurement of the Emotion Regulation Questionnaire (ERQ) and the Family Assessment Device (FAD). Then, the results and discussion of the research are in Section 4. Finally, Section 5 concludes the paper and presents direction for future research.

\section{BACKGROUND}

\subsection{Family Functioning}

\subsubsection{Definition of Family Functioning}

According to Epstein, Baldwin and Bishop [20], family functioning is the interaction of each family member to achieve functions and goals in a family. The concept of The McMaster Model of Family Functioning proposed by Epstein, Baldwin and Bishop [20] states that family functioning is closely related to the systematic and transactional set of families compared to the intrapsychic characteristics of each individual family member.

\subsubsection{Dimensions of Family Functioning}

According to The McMaster Model of Family Functioning by Epstein, Bishop and Levin [21] and Epstein, Baldwin, and Bishop [20], there are seven dimensions of family functioning.

\subsubsection{Problem Solving}

Problem solving is defined as the ability of a family to solve problems until it achieves effective family functioning. Problems in the family are seen as an issue that threatens the integrity and capacity of family functioning.

Generally, problems in the family are divided into two areas, namely: (a) instrumental problems, namely problems relating to everyday life, such as finances and household; and (b) affective problems, namely problems relating to feelings.

A family that is unable to solve the two types of problems above is considered a very ineffective family, if only able to solve one of them will be considered an effective family, and if it is able to solve both types it is considered 
a very effective family. Effective is meant here is to solve problems quickly, easily and without much consideration.

\subsubsection{Communication}

Communication refers to how family members exchange information, especially verbally. Communication is also divided into two areas, namely the instrumental and affective areas.

Generally, there are two independent dimensions, namely: (a) clear vs masked continuum; and (b) direct vs indirect communication. These two dimensions make four communication patterns, namely: (a) clear and direct, (b) clear and indirect, (c) masked and direct, and (d) masked and indirect.

\subsubsection{Roles}

Roles refers to the role of each family member with a pattern of behavior that repeats itself to fulfil a role in the functioning of the family.

Based on the role dimension, there are two role concepts, namely: (a) role allocation refers to the concept of assigning responsibility to family functions, such as whether the allocation is appropriate and whether the allocation process is carried out implicitly or explicitly by dictum or by open and free discussion; and (b) role accountability refers to the process by which family members become responsible for the responsibilities that have been allocated to them.

\subsubsection{Affective Responsiveness}

Affective responsiveness refers to how the ability to respond to various stimuli with the appropriate quantity and quality of feelings.

Affective responsiveness is divided into two, namely: (a) welfare feelings, such as affection, tenderness, happiness and joy; and (b) emergency feelings, such as fear, anger, sadness, disappointment and depression.

\subsubsection{Affective Involvement}

Affective involvement refers to the extent to which the family shows a sense of interest in the interests and activities of family members.

There are six possibilities for affective involvement in the family, namely: (a) lack of involvement, (b) involvement devoid of feelings, (c) narcissistic involvement, (d) empathic involvement, (e) over-involvement, and (f) symbiotic involvement.

\subsubsection{Behavior Control}

Behavior control refers to how the family adopts in dealing with behavior in three specific situations, namely: (a) physically dangerous situations, (b) situations that involve meeting and expressing biological needs and drives, and (c) situations involving socializing behavior with outsiders and in the family.

There are four types of behavior control, namely: (a) rigid behavior control, (b) flexible behavior control, (c) laissezfaire behavior control, and (d) chaotic behavior control.

\subsubsection{General Functioning}

General functioning refers to the functioning of the family as a whole.

\subsection{Emotional Regulation}

\subsubsection{Definition of Emotional Regulation}

According to Gross [22], emotion regulation refers to how individuals affect the emotions they have, when individuals have and how individuals experience and express these emotions. Emotion regulation can be done automatically or controlled, consciously or unconsciously, and has one or more effects in the emotion-generative process [23].

\subsubsection{Process Model of Emotion Regulation}

According to Gross [22], in regulating emotions there are five series of process models developed from the concept of Gross and Thompson's capital model in 2007. The processes for regulating emotions are: (a) situation selection. Situation selection is an action that allows individuals to choose or consider the consequences of an emotional response from the choices to be faced. Situation selection allows individuals to reduce or increase the emotions they want to have by taking steps to minimize unwanted or less desirable emotional states; (b) situation modification. Situation modification is an individual attempt to modify a situation and condition directly to give rise to a new situation and condition. Situation modification can be done by modifying the external physical environment or the circumstances around the individual; (c) attentional deployment. Attentional deployment is an action to influence emotional response by diverting attention in certain situations and conditions. Attentional deployment is an internal version of situation selection in which attention is used to select or consider an "internal situation" from the many possibilities that exist at a given time; (d) cognitive change. Cognitive change refers to changing one or more of the cognitive assessments in a way that changes the emotional meaning of the current situation, as well as changing the way individuals think about the current situation or about their capacity to manage the demands it brings; and (e) response modulation. Response modulation refers to how an individual influences physiological, experiential or direct behavioral responses. Gross mentions this theory as a model process for emotional regulation, but these stages can be carried out without going through the entire process 
or stage. For example, individuals can regulate their emotions by directly engaging in the cognitive change process by going through the stages of situation selection, situation modification and attentional deployment [24].

\subsubsection{Dimensions of Emotional Regulation}

According to Gross and Thompson [23] and Gross [22], there are two dimensions of emotional regulation.

\subsubsection{Cognitive Reappraisal}

Cognitive reappraisal is defined as cognitive changes that involve a change in the meaning of a situation in such a way that it causes changes in an individual's emotional response to the situation.

For example, when an individual greets another person, but that person ignores it, the natural response that the individual will experience is usually anger, shame or hurt. Thus, cognitive changes will alter this natural response by thinking that the person is distracted or is focused on his own problems. Such thinking affects the quality (which emotion) and the quantity (how much) of subsequent emotional responses.

\subsubsection{Expressive Suppression}

Expressive suppression is defined as one form of response modulation which refers to efforts to reduce ongoing emotional expressive behavior (response-focused). For example, when individuals hold their anger at their boss or anxiety during an interview. Therefore, it can be said that expressive suppression is effective in reducing the expression of negative emotional responses.

\section{METHODS}

\subsection{Participants}

The participant of this research are 114 undergraduate students at the age between 18-24 years old. This research is not limited to certain religious, ethnic or racial groups. This study also does not limit the subject's domicile of residence, but the subject must reside with the family or return home once a week while being an undergraduate student or at least communicate with family within one week with frequency always, often or sometimes. The research subject must be an active undergraduate student who comes from a University, Institute, College or the like.

\subsection{Measures}

\subsubsection{Family Assessment Device (FAD)}

Family Assessment Device (FAD) made by Epstein, Baldwin and Bishop in 1983. FAD uses a Likert scale consisting of seven answer choices that are in the range from 1, namely Strongly Disagree (SD) to 4, namely Strongly Agree (SA)

FAD has a total of 53 question items that have good validity and reliability with alpha for the subscales ranging from 0.72 to 0.92 .

The FAD scale is arranged based on the dimensions of family functioning according to The McMaster Model of Family Functioning (MMFF) which was later developed by Epstein et. al in 1983 so that it consists of seven dimensions with a total of 53 question items.

After testing the validity and reliability using the Cronbach Alpha formula on the seven dimensions tested, the FAD items that were discarded were items $03,12,17,22,24$, $31,38,39,42,43$, and 44 which make up changes in the overall Cronbach Alpha value from 0.922 to 0.940. Thus, after being tested, of the 53 statement items, only 42 items remained.

\subsubsection{Emotion Regulation Questionnaire (ERQ)}

Emotion Regulation Questionnaire (ERQ) was developed by Gross and John (2003), which is used to measure how the participants tend to regulate their emotions. This ERQ uses a Likert scale consisting of seven answer choices that are in the range from 1, namely Strongly Disagree (SD) to 7, namely Strongly Agree (SA) so in other words that the greater the number chosen by the subject, the more agreeable it is. also subject to the available statements.

ERQ has two dimensions, namely the cognitive reappraisal dimension with a total of 6 items and an expressive suppression dimension with a total of 4 items, so that the total of this ERQ is 10 items.

After the validity and reliability tests were carried out using the Cronbach Alpha formula on both dimensions, the ERQ items that were discarded were items 2 and 4 which caused a change in the overall Cronbach Alpha value from 0.563 to 0.632 . Thus, after being tested, of the 10 statement items, only 8 items remained.

\section{FINDINGS AND DISCUSSIONS}

In testing the normality of the data, the researcher used one sample Kolmogorov-Smirnov by using unstandardized residuals on the two research variables so that the Kolmogorov-Smirnov $\mathrm{Z}=0.072$ and $\mathrm{p}=0.2>0.05$ results so that it can be concluded that in this study the data group on the two variables met the requirements minimum in normality test or in other words, the data is normally distributed.

Based on the linear regression analysis conducted by the researcher, the results obtained were $\mathrm{R}=0.524$, $\mathrm{R}$ Square $=0.274$, and Adjusted R Square $=0.268$. $\mathrm{R}$ square is the coefficient of determination in linear regression which is used to measure how much the ability of IV to explain the variance of DV which comes from the result of the square of $\mathrm{R}(0.524 \times 0.524)$ so that if it is used as a percentage, it will be $27.4 \%$. This means that the role of family functioning in emotional regulation is $27.4 \%$, of which 
$72.6 \%(100 \%-27.4 \%)$ is the role of other factors that are outside of this study.

Based on the existing variables, there are two hypotheses in this study, namely: (a) H0, which means that the regression coefficient is not significant; and (b) $\mathrm{Hi}$, which means the regression coefficient is significant. Based on the linear regression analysis that has been carried out by researchers, the ANOVA results were obtained, namely $\mathrm{F}$ $=42.37$ with a significance level of 0.0000 , because $0.0000<0.05$, then there is a significant effect. In addition, the results of the $\mathrm{t}$ test were also obtained, namely $\mathrm{t}=$ $6,509>1,981$ with a degree of freedom of $112(114-2)$ and a significance level of $0.000<0.05$. Because the result of $t$ count is greater than $t$ table and the level of significance is smaller than 0.05 , there is a significant effect.

Testing with the Confirmatory Factor Analysis (CFA) model aims to identify the right model that explains the relationship between a set of items and the construct measured by the item. The measurement model has good model accuracy when the items involved are able to be indicators of the construct being measured as evidenced by a low measurement error value and a high loading factor of the manifest variable. In addition, through CFA testing, researchers can find out which manifest variables or dimensions are the most dominant for latent variables or measuring constructs. After testing, it was found that chisquare $=66.53>0.05 ; \mathrm{df}=26 ; \mathrm{p}$-value $=0.00002<0.05$; and RMSEA $=0.12>0.08$.

Table 1 Goodness of fit index

\begin{tabular}{cccc}
\hline $\begin{array}{c}\text { Goodness of } \\
\text { fit index }\end{array}$ & $\begin{array}{c}\text { Cut-off } \\
\text { value }\end{array}$ & $\begin{array}{c}\text { Research } \\
\text { Model }\end{array}$ & Information \\
\hline GFI & $\geq 0.90$ & 0.88 & Marginal fit \\
AGFI & $\geq 0.90$ & 0.80 & Marginal fit \\
CFI & $\geq 0.90$ & 0.95 & Good fit \\
\hline
\end{tabular}

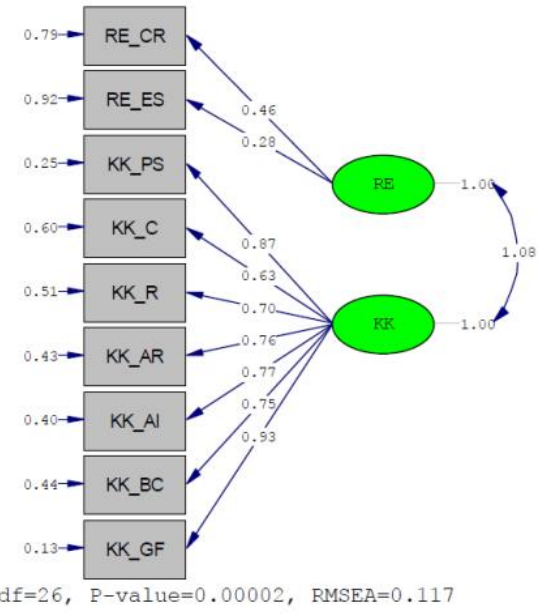

Figure 1 Confirmatory Factor Analysis (CFA)
Table 2 Confirmatory Factor Analysis (CFA)

\begin{tabular}{|c|c|c|c|}
\hline $\begin{array}{l}\text { Indicator } \\
\text { Codes }\end{array}$ & $\begin{array}{c}\text { Standardize } \\
\text { d Loading } \\
\text { Factors } \\
(\mathrm{SLF}) \geq 0.5\end{array}$ & $\begin{array}{l}\text { Standar } \\
\text { d Errors }\end{array}$ & $\begin{array}{c}\text { Informatio } \\
n\end{array}$ \\
\hline Cognitive & 0.46 & 0.79 & $\mathrm{Bad}$ \\
\hline Reappraisal & & & Validity \\
\hline Expressive & 0.28 & 0.92 & $\mathrm{Bad}$ \\
\hline Suppression & & & Validity \\
\hline Problem & 0.87 & 0.25 & Good \\
\hline Solving & & & Validity \\
\hline $\begin{array}{c}\text { Communicatio } \\
\mathrm{n}\end{array}$ & 0.63 & 0.60 & $\begin{array}{c}\text { Good } \\
\text { Validity }\end{array}$ \\
\hline Roles & 0.70 & 0.51 & $\begin{array}{c}\text { Good } \\
\text { Validity }\end{array}$ \\
\hline $\begin{array}{c}\text { Affective } \\
\text { Responsivenes } \\
\text { s }\end{array}$ & 0.76 & 0.43 & $\begin{array}{c}\text { Good } \\
\text { Validity }\end{array}$ \\
\hline Affective & 0.77 & 0.40 & Good \\
\hline $\begin{array}{c}\text { Involvement } \\
\text { Behavior } \\
\text { Control }\end{array}$ & 0.75 & 0.44 & $\begin{array}{l}\text { Validity } \\
\text { Good } \\
\text { Validity }\end{array}$ \\
\hline $\begin{array}{c}\text { General } \\
\text { Functioning }\end{array}$ & 0.93 & 0.13 & $\begin{array}{c}\text { Good } \\
\text { Validity }\end{array}$ \\
\hline
\end{tabular}

So, it can be concluded that in the family functioning variable, the most dominant dimension is general functioning with loading factors of 0.93 , and the least dominant is communication with loading factors of 0.63 . Meanwhile, in the emotional regulation variable, the most dominant dimension was cognitive reappraisal with loading factors of 0.46 , and the least dominant was expressive suppression with loading factors of 0.28 .

This research is based on previous studies, namely Uci and Savira [14] and Saifullah and Djuwairiyah [19] which state that family function has a positive and significant relationship with emotional regulation so that the hypothesis in this study is obtained, namely the role of family functioning. which is positive and significant towards emotional regulation in undergraduate students.

Based on the results of the regression analysis in this study, it was found that there was a role for family functioning in emotional regulation even though the role of $72.6 \%$ was held by other factors that were not in this study. In additional tests, researchers found a relationship between emotional regulation with birth order, semester, and place of residence, which means that these three things become other factors in individuals regulating their emotions.

In this study, the primary criteria for the subjects used were undergraduate students aged 18-24 years and came from an intact family; while the secondary criteria for the subject used are living with parents and nuclear family or alone, but still returning to the family home with a frequency of at least once per week or at least having a frequency of communication with family that ranges always, often and sometimes within a period of time one week. Based on the primary and secondary subject criteria, 
there were 114 subjects covering both of these criteria, which were known to be mostly female students.

Although this research has been carried out well, the researcher realizes that this research is still far from perfect and has its own limitations, namely that this study cannot measure the role of family functioning in emotional regulation in subjects with families whose father and/or mother died and their parents divorced. In addition, due to time constraints, there were not too many participants which allowed for bias in this study.

\section{CONCLUSIONS}

The results of this study indicate that there is a role for family functioning on emotional regulation in undergraduate students, so based on the results of the research analysis, it is concluded that there is a positive and significant role of family functioning at $27.4 \%$, so it can be said that if the functioning in the family increases, then emotional regulation will increase.

\section{REFERENCES}

[1] Nurnaini, K. (2014). Motivasi berprestasi mahasiswa penyandang tunadaksa (Undergraduate thesis, Universitas Islam Negeri Sunan Ampel). Retrieved from http://digilib.uinsby.ac.id/387/

[2] Hidayatulloh, L. I. (2014). Optimalisasi fungsi pembimbing akademik bagi sukses studi mahasiswa (Studi Empiris pada Fakultas Agama Islam Universitas Muhammadiyah Surakarta Angkatan 2011) (Undergraduate thesis, Universitas Muhammadiyah Surakarta). Retrieved from http://eprints.ums.ac.id/ 30845/

[3] Hidayat, D. R. (2011). Permasalahan mahasiswa. Kopertis 3. Retrieved from http://www.kopertis3.or.id/ $\mathrm{html} / \mathrm{wp}$-content/uploads/2011/04/permasalahanmahasiswa-untuk-kopertis-wilayah-iii.pdf

[4] Behere, S. P., Yadav, R., \& Behere, P. B. (2011). A comparative study of stress among students of medicine, engineering and nursing. Indian Journal of Psychological Medicine, 33(2), 145-148. DOI: 10.4103/ 0253-7176.92064

[5] Alfian, M. (2014). Regulasi emosi pada mahasiswa Suku Jawa, Suku Banjar dan Suku Bima. Jurnal Ilmiah Psikologi Terapan, 2(2), 263-275. DOI: https://doi.org/ 10.22219/jipt.v2i2.2001

[6] Barseli, M., Ifdil, \& Nikmarijal (2017). Konsep stres akademik siswa. Jurnal Konseling dan Pendidikan, 5(3), 143-148. Retrieved from https://jurnal. konselingindonesia.com/index.php/jkp/article/view/198 /209

[7] Alwazir, E. (2014). Menghadapi masalah, antara menyelesaikan dan memecahkan. Kompasiana. Retrieved from https://www.kompasiana.com/erwinal wazir/54f3b4797455137c2b6c7e19/menghadapimasalah-antara-menyelesaikan-dan-memecahkan

[8] Mahpudin, H. (2018). Efektif dan efisien: Pengertian, perbedaan dan contohnya, lengkap. Salamadian. Retrieved from https://salamadian. com/ pengertian-efektif-dan-efisien/

[9] Silaban, F. F. (2015). Manfaat saat anda punya kecerdasan emosional. Liputan6. Retrieved from https://www.liputan6.com/lifestyle/read

/2364896/manfaat-saat- anda-punya-kecerdasanemosional

[10] Silaen, A. C., \& Dewi, K. S. (2015). Hubungan antara regulasi emosi dengan asertivitas (Studi korelasi pada siswa di SMA Negeri 9 Semarang). Jurnal Empati, 4(2), 175-181. Retrieved from https://media. neliti.com/media/publications/64750-ID-hubunganantara-regulasi-emosi-dengan-as.pdf

[11] Retnowati, S., Widhiarso, W., \& Rohmani, K. W. (2003). Peranan keberfungsian keluarga pada pemahaman dan pengungkapan emosi. Jurnal Psikologi, 30(2), 91-104. DOI: 10.22146/jpsi.7028

[12] Islamiyah, A., Sismawati, M., \& Kaloeti, D. V. S. (2020). Pengaruh psikoedukasi mindfulness singkat pada kemampuan regulasi emosi mahasiswa. Jurnal Ilmiah Psikologi Terapan, 8(1), 66-74. Retrieved from http://ejournal.umm.ac.id/index.php/jipt/article/view/ 9444

[13] Handayani, L. (2018). Keluarga merupakan pendidik pertama dan utama. Kompasiana. Retrieved from https://www.kompasiana.com/lina 73569/5b3e474 eab12ae4270492552/keluarga-merupakan-pendidikpertama-dan-utama

[14] Uci, I. R., \& Savira, S. I. (2019). Hubungan antara keberfungsian keluarga dengan regulasi emosi pada siswa di SMP X Surabaya. Jurnal Penelitian Psikologi, $6(2)$, 1-7. Retrieved from https://jurnalmahasiswa. unesa.ac.id/ index.php/character/article/view/28359

[15] Ainiyah, Q. (2017). Social learning theory dan perilaku agresif anak dalam keluarga. Jurnal Ilmu Syari'ah dan Hukum, 2(1), 91-104. Retrieved from http://ejournal.iainsurakarta.ac.id/index.php/al-ahkam/ article/view/789/242 
[16] Kurniawati, H. (2018). Hubungan keberfungsian keluarga dengan kompetensi sosial yang dimediasi oleh regulasi emosi pada remaja delinkuen (Master-Program Thesis). Retrieved from http://eprints.umm.ac.id/40002/

[17] Herawaty, Y., \& Wulan, R. (2013). Hubungan antara keberfungsian keluarga dan daya juang dengan belajar berdasar regulasi diri pada remaja. Jurnal Psikologi, 9(2), 138-147. DOI: http://dx.doi.org/10. 24014/jp.v9i2.176

[18] Yahya, M., \& Bahri, S. (2016). Identifikasi masalah-masalah yang dialami mahasiswa Fakultas Teknik dan Ekonomi UNSYIAH. Jurnal Suloh: Jurnal Bimbingan Konseling FKIP UNSYIAH, 1(1). Retrieved from http://e-repository.unsyiah.ac.id/suloh/article/ view/8257

[19] Saifullah \& Djuwairiyah. (2019). Peran keberfungsian sistem keluarga pada regulasi emosi remaja. M@ddah, 1(2). Retrieved from https:// journal.ibrahimy.ac.id/index.php/maddah/article/downl $\mathrm{oad} / 510 / 484 /$

[20] Epstein, N. B., Baldwin, L. M., \& Bishop, D. S. (1983). The McMaster Family Assessment Device. Journal of Marital and Family Therapy, 9(2), 171-180. DOI: $\quad$ https://doi.org/10.1111/j.1752-0606.1983.tb 01497.x

[21] Epstein, N. B., Bishop, D. S., \& Levin, S. (1978). The McMaster Model of Family Functioning. Journal of Marital and Family Therapy, 4(4), 19-31. DOI: 10.1111/j.1752-0606.1978.tb00537.x

[22] Gross, J. J. (2008). Emotion Regulation. Dalam Lewis, M., Jones, J. M. H., \& Barrett, L. F. (Eds.), Handbook of emotions (p. 497-512). New York: The Guilford Press.

[23] Gross, J. J., \& Thompson, R. A. (2007). Emotion Regulation: Conceptual Foundations. Dalam J. J. Gross (Ed.), Handbook of emotion regulation (p. 3-24). New York: The Guilford Press.

[24] Zuraidha, V. N. (2012). Regulasi emosi dan happiness pada siswa kelas X Program Reguler dan Akselerasi SMA Negeri 3 Malang (Undergraduate thesis, Universitas Islam Negeri Maulana Malik Ibrahim). Retrieved from http://etheses.uinmalang.ac.id/2224/ 